\title{
STUDI PEMBUATAN SERBUK EFFERVESCENT TEMULAWAK \\ (Curcuma xanthorrhiza Roxb) \\ KAJIAN SUHU PENGERING, KONSENTRASI DEKSTRIN, KONSENTRASI ASAM SITRAT \\ DAN Na-BIKARBONAT
}

Rakhmad Wiyono

\begin{abstract}
This research aimed to get the combination of drying temperature and dextrin concentration against the quality of temulawak's essence, and the combination between citric acid and Na- Bicarbonate treatment against temulawak's effervescent powder quality.

The result of the first step shows that the treatment combination between $20 \%$ of dextrin concentration and $50^{\circ} \mathrm{C}$ of drying temperature which is the best treatment of the first step from temulawak's powder essence that has characteristics on $10.11 \%$ of water content, ( $\mathrm{L}^{*}$ ) 55.10 of brightness level, ( $\left.\mathrm{a}^{*}\right) 14.56$ of redness level, ( $\left.\mathrm{b}^{*}\right) 44.20$ of yellowness level, $24.63 \%$ of rendement, 5.63 of pH; 2.78 of water re-absorption; $1.88 \%$ of sugar content reduction; $62.27 \%$ antioxidant content, 5.55 obtains panellists' assessment against color, 5.95 of taste, and 4.15 of aroma.

The result of the second step shows that the treatment combination between $10 \%$ citric acid and $20 \%$ Na-bicarbonate that is the best treatment of the second step that has characteristics on $7.48 \%$ of water content, (L*) 59.37 of brightness level, (a*) 14.53 of redness level, (b*) 46.50 of yellowness level, 5.33 of pH, 88.17 of dissolving rate, $2.49 \%$ of sugar content reduction, and $46.53 \%$ of antioxidant content.

The conclusion of this research is the best treatment combination on the first step is $20 \%$ of dextrin concentration and $50^{\circ} \mathrm{C}$ drying temperature, while at the second step is $10 \%$ citric acid concentration and $20 \%$ Na-bicarbonate. The advice of this research is its necessary to analyze the curcuminoid content as an active antioxidant compound in temulawak.
\end{abstract}

Key word : Effervescent powder, temulawak

Abstrak: Penelitian ini bertujuan untuk mendapatkan kombinasi suhu pengeringan dan konsentrasi dekstrin terhadap kualitas sari temulawak dan kombinasi perlakuan asam sitrat dan Na-Bicarbonat terhadap kualitas serbuk effervescent temulawak.

Hasil penelitian pada Tahap I menunjukkan bahwa kombinasi perlakuan konsentrasi dekstrin $20 \%$ dan suhu pengering $50^{\circ} \mathrm{C}$ merupakan perlakuan terbaik tahap I dari serbuk sari temulawak yang memiliki karakteristik kadar air 10,11\%; tingkat kecerahan (L*) 55,10; tingkat kemerahan (a*) 14,56; tingkat kekuningan (b*) 44,20; rendemen 
24,63\%; pH 5,63; reabsorbsi air 2,78; kadar gula reduksi 1,88\% dan kadar antioksidan $62,27 \%$ sedangkan rerata tingkat kesukaan panelis terhadap warna 5,55; rasa 5,95 dan aroma 4,15 .

Hasil penelitian pada Tahap II menunjukkan bahwa kombinasi perlakuan konsentrasi asam sitrat 10\% dan natrium bikarbonat 20\% merupakan perlakuan terbaik tahap II yang memiliki karakteristik kadar air 7,48\%; tingkat kecerahan ( $\left.\mathrm{L}^{*}\right)$ 59,37; tingkat kemerahan (a*) 14,53; tingkat kekuningan (b*) 46,50; pH 5,33; kelarutan 88,17; kadar gula reduksi 2,49\% dan kadar antioksidan 46,53\%.

Kesimpulan dari penelitian ini adalah kombinasi perlakuan terbaik pada Tahap I yaitu, konsentrasi dekstrin $20 \%$ dan suhu pengering $50^{\circ} \mathrm{C}$ dan Tahap II yaitu, konsentrasi asam sitrat $10 \%$ dan natrium bikarbonat $20 \%$. Saran dari penelitian ini perlu dilakukan analisa kadar kurkuminoid sebagai senyawa antioksidan aktif yang terdapat dalam temulawak.

Kata Kunci : Serbuk effervescent, Temulawak

\section{PENDAHULUAN}

Temulawak

xanthorrhiza Roxb), merupakan tumbuhan asli Indonesia. Dari sekitar 70 jenis Curcuma yang tersebar di kawasan Asia Selatan. Asia Tenggara sampai ke Australia Utara, tidak kurang 20 jenis tumbuh di Indonesia. Rimpang ini paling banyak digunakan sebagai bahan baku obat tradisional. Di samping itu, rimpang tanaman ini juga merupakan salah satu bahan eksport yang cukup potensial. Kebutuhan akan temulawak dari tahun ketahun semakin meningkat dengan berkembangnya perusahaan obat tradisional di Indonesia (Yoganingrum, 1997).

Sebagai obat tradisional telah diketahui manfaatnya oleh nenek moyang sejak jaman dahulu, temulawak paling umum dipakai ramuan jamu untuk tambah nafsu makan, gangguan hati, penyakit kuning malaria, tambah nafsu makan, pegal-pegal dan sembelit baik berupa air perasan maupun air rebusan. Hadi (1999), telah membuktikan khasiatnya melalui teknik ilmu pengetahuan modern baik oleh ilmuwan dalam maupun luar negeri. Hasil-hasil penelitian membuktikan bahwa temulawak mempunyai berbagai macam khasiat, yaitu : sebagai analgesik, antibakteri, antidiabetik, antidiare, antiinflamasi, antihepatotoksik, insektisida dan lainlain.

Kandungan kimia rimpang temulawak yang memberi arti pada penggunaannya sebagai sumber bahan pangan, bahan baku industri, atau bahan baku obat dapat dibedakan atas beberapa fraksi, yaitu : fraksi pati, fraksi kurkuminoid, dan fraksi minyak atsiri (Sidik, 1999).Pada saat ini telah banyak perusahaan obat tradisional 
yang memproduksi jamu dalam bentuk ekstrak, sehingga sedikit demi sedikit akan menggantikan sebagian jamu bentuk serbuk (terikut ampasnya) yang dikatakan kurang efisien. Perusahaan obat tradisional melakukan penyarian bahan dengan cara menggodog rajangan dan serbuk bahan dengan air panas. Hal ini akan menyebabkan gugus aktif bahan penyusun jamu yang tersari kurang efektif (Pramono, 1999). Oleh karena itu dicari teknik pengolahan yang tidak banyak merusak gugus aktif.Serbuk effervescent merupakan alternatif pengembangan produk minuman ringan yang menarik dan memberikan variasi dalam penyajian minuman tradisional juga praktis dalam penyimpanan dan transportasi dibanding minuman ringan biasa dalam bentuk cair.

Keunggulan serbuk effervescent dibanding minuman serbuk biasa adalah kemampuan untuk menghasilkan gas karbondiksida $\left(\mathrm{CO}_{2}\right)$ yang memberikan rasa segar seperti pada air soda. Kartika (2000), adanya gas tersebut akan menutupi rasa pahit serta mempermudah proses pelarutannya tanpa melibatkan pengadukan secara manual, dengan syarat semua omponennya bersifat sangat mudah larut dalam air.Komponen penyusun minyak atsiri antara lain, Germakron berbentuk kristal jarum tidak berwarna mempunyai bobot molekul 218, rumus molekul $\mathrm{C}_{15} \mathrm{H}_{22} \mathrm{O}$. dengan titik leleh 53 $-55^{\circ} \mathrm{C}$ (Sidik, 1999). Oleh karena itu, pengolahan rimpang temulawak diperlukan perlakuan suhu pengeringan dibawah titik leleh, untuk mempertahankan gugus aktif temulawak yang merupakan salah satu penentu kualitas produk.

Teknologi pengeringan yang mudah diterapkan dan murah yaitu metode foam-mat draying. Penambahan bahan pengisi seperti dekstrin diperlukan dalam pembuatan bubuk sari temulawak dengan metode foam-mat draying, dengan tujuan untuk mempercepat pengeringan dan mencegah kerusakan akibat panas, melapisi komponen flavour, meningkatkan total padatan, dan memperbesar volume (Murtala, 1999). Penggunaan pengeringan dengan suhu $50 \pm 2^{0} \mathrm{C}$ dan penambahan dekstrin $12,5 \%$ menghasilkan produk terbaik pada pembuatan bubuk sari buah sirsak (Suryanto, 2000) Teknologi pengeringan ini, diharapkan dapat mendukung pengembangan temulawak menjadi bentuk bubuk sari temulawak yang berkualitas.

Dalam minuman terkarbonasi dan minuman bubuk asam sitrat dapat memberikan rasa jeruk yang tajam. Asam sitrat yang digunakan dalam effervescent umumnya dalam bentuk monohidrat didapatkan dari kristalisasi asam sitrat dalam air dingin bentuk monohidrat tersebut dapat diubah menjadi bentuk anhydraus dengan pemanasan diatas $74^{\circ} \mathrm{C}$ (Anonymous, 2007). Asam sitrat sering digunakan sebagai sumber asam dalam pembuatan serbuk atau tablet effervescent karena memiliki kelarutan yang tinggi dalam 
air dingin, mudah didapat dalam bentuk granular atau serbuk.

Na-Bikarbonat

$\left(\mathrm{NaHCO}_{3}\right)$

merupakan serbuk kristal putih yang mampu menghasilkan karbondioksida. Na-Bicarbonat memiliki berat molekul 84,01 (tiap gramnya mengandung $11,9 \mathrm{mmol}$ natrium). Na-Bicarbonat anhidrat terkonversi pada suhu $250^{\circ} \mathrm{C}$ $300^{\circ} \mathrm{C}$, pada $\mathrm{RH}$ di atas $85 \%$ akan menyerap air dari lingkungannya dan menyebabkan dekomposisi dengan hilangnya karbondioksida (Reynolds, 1989). Pada pembuatan effervescent mengkudu yang dilakukan oleh Wardiningrum (2001), penggunaan Na-Bicarbonat $\left(\mathrm{NaHCO}_{3}\right) \quad 32 \%$ merupakan hasil yang tebaik. Pada pembuatan effervescent ubi jalar ungu digunakan Na-Bicarbonat $\left(\mathrm{NaHCO}_{3}\right)$ $10 \%$.

Sejauh ini penelitian pembuatan serbuk effervescent dari temulawak dengan menggunakan kombinasi kajian suhu pengering, dekstrin, asam sitrat dan Na-Bicarbonat $\left(\mathrm{NaHCO}_{3}\right) \quad$ belum banyak diungkapkan.

\section{TINJAUAN PUSTAKA} Karakteristik Temulawak

Temulawak

(Curcuma xanthorrhiza Roxb) termasuk famili Zingberaceae. Temulawak satu famili dengan anggota temu-temuan lainnya, yakni temu hitam (Curcuma aeruginosa), kunyit (Curcuma domestica Val.), kencur (Kaempferia galanga) dan jahe (Zingiber officinale Rosc). Di sepanjang daerah tropis dan subtropis, famili Zingiberaceae terdiri dari 47 genus dan 1400 spesies (Afifah, 2003).

Temulawak

(Curcuma xanthorriza Roxb) merupakan tanaman asli Indonesia yang tumbuh liar di hutan-hutan beberapa pulau di Indonesia seperti Jawa, Madura, Maluku, Kalimantan, Bali, dan Nusa Tenggara Temulawak sering kali dikaitkan dengan kehadiran suku jawa. Dengan meluasnya penggunaan temulawak, saat ini sudah dilakukan pembudidayaan terutama di Pulau jawa (Rukmana, 2000).

Tumbuhan

menyukai lingkungan lembab terlindung, sehingga sering tumbuh di hutan jati atau hutan bambu. Tanaman temulawak merupakan tanaman hutan, namun dapat tumbuh ditempat yang agak cerah (Ramlan, 1999). Temulawak dapat ditanam pada tanah yang agak berpasir sampai tanah berat bertekstur liat, dan dapat tumbuh pada ketinggian 5 - 1.500 meter diatas permukaan laut (Hargono, 1985).

Temulawak termasuk tananaman berbatang semu basah, berwarna hijau atau coklat gelap, membentuk rumpun yang tingginya bervariasi. Ada yang mencapai 0,5 2,5 $\mathrm{m}$ tergantung keadaan lingkungan tumbuhnya. Daunnya melebar panjang mirip daun pisang dan tiap tanaman mempunyai daun antara $2-9$ helai, berwarna hijau atau coklat keunguan terang sampai gelap dengan ukuran panjang $31-84 \mathrm{~cm}$ dan lebar antara $10-18 \mathrm{~cm}$. Tanaman temulawak 
membentuk rimpang induk bulat panjang dengan anak rimpang sebanyak $3-7$ buah. Permukaan luar rimpang berkerut dan berwarna coklat kuning sampai coklat sedangkan bidang irisannya berwarna coklat kuning buram, melengkung tidak

beraturan / tidak rata, sering dengan tonjolan melingkar pada batas antara silinder pusat dengan korteks (Syamsudin, 1999).

Bunga muncul dari camping batang, berbentuk bulir bulat memanjang dengan panjang antara 9-23 $\mathrm{cm}$ dan lebar 4-6 cm. Daun pelindung bunga banyak dan panjangnya melebihi atau sama dengan mahkota bunga, berbentuk bulat telur sungsang sampai bentuk jorong berwarna merah, ungu atau putih. Wahid, (1999), kelopak bunga berwarna putih dan mahkota bunga berbentuk tabung dengan panjang keseluruhan 4-5 cm. Tabung berwarna putih atau kuning, berukuran $2-2,5 \mathrm{~cm}$ Benang sari berwana kuning muda dengan ukuran panjang 12 - $16 \mathrm{~mm}$, lebar $10-15 \mathrm{~mm}$, tangkai sari panjang $3-4,5 \mathrm{~mm}$, lebar 2,5 - 4,5 mm. Kepala sari berwarna putih, panjang $6 \mathrm{~mm}$, tangkai putik panjang 3 $-7 \mathrm{~mm}$, buah berbulu panjang $20 \mathrm{~mm}$.

\section{Potensi dan Produksi Temulawak}

Tanaman temulawak merupakan salah satu tanaman obat yang mempunyai prospek cerah untuk dikembangkan. Anonymous, (2004), eksport temulawak Indonesia th 2003 sebesar 5,452 juta dolar AS dengan volume 9,149 ton. Pengembangan tanaman temulawak di Indonesia sangat potensial karena didukung dengan jumlah produksi rimpang temulawak yang mengalami peningkatan sejak 2001 - 2002. Jumlah prosi rimpang temulawak pada tahun 1998 - 2002 dapat dilihat pada Tabel 1.

\section{Tabel 1. Jumlah Produksi Rimpang Temulawak}

\begin{tabular}{|c|c|}
\hline Tahun & Jumlah produksi (kg) \\
\hline 1998 & 11.559400 \\
\hline 1999 & 4.615 .800 \\
\hline 2000 & 5.674 .100 \\
\hline 2001 & 6.089 .077 \\
\hline 2002 & 7.173 .513 \\
\hline
\end{tabular}

Sumber : BPS di dalam Statistika

Pertanian (2003).

\section{Khasiat Rimpang Temulawak}

Tumbuhan temulawak secara empirik banyak digunakan sebagai obat dalam bentuk tunggal maupun campuran untuk mengatasi saluran pencernaan, gangguan aliran getah empedu, sembelit, radang rahim, kencing nanah, kurang nafsu makan, obesitas, radang lambung, cacar air, ambeien, perut kembung, memulihkan kesehatan sehabis melahirkan (Afifah, 2003).

Komposisi kimia dari rimpang temulawak adalah protein pati sebesar 29 - 30 persen, kurkumin 1 - $2 \%$, dan minyak atsiri 6 - 10 persen. Daging buah rimpang temulawak mempunyai kandungan senyawa kimia antara lain berupa fellandrean dan tumerol atu yang sering disebut minyak menguap. Kemudian minyak atsiri, kamfer, 
glukosida, foluymetik karbinol. Temulawak mengandung minyak atsiri seperti limonina yang mengharumkan, sedangkan kandungan flavonoida-nya berkasiat menyembuhkan radang, minyak atsiri juga bisa membunuh mikroba. Kurkumin yang terdapat pada rimpang tumbuhaan ini bermanfaat sebagaai acnevulgaris, disamping sebagai anti inflamasi, antioxidan, anti hepototoksik (anti keracunan empedu) dan anti tumor (Sidik, 1999).

Ramuan untuk menyembuhkan kanker dapat dikonsumsi jika penyakit ini masih dalam stadium dini, namun bila tak kunjung ada perubahan atau tanda membaik setelah minum ramuan obat selama dua bulan, sebaiknya berkonsultasi dengan dokter. Mangan, (2004) ramuan untuk mengobati kanker dapat dikonsumsi segera setelah menjalani operasi pengangkatan kanker dan radiasi. Hal ini dimaksudkan untuk memutus rantai sel kanker yang mungkin masih tertinggal. Sementara itu, jika menjalani pengobatan dengan kemoterapi, ramuan diminum dua minggu sejak kemoteri dilakukan.

Jika dokter memberi obat, ramuan sebaiknya diminum dua jam sebelum atau sesudah mengkonsumsi obat dari dokter. Rimpang temulawak mengandung kurkumin dan monodestmetoksi kurkumin yang bersifat anti tumor. Temulawak juga berkasiat menghilangkan rasa nyeri dan sakit karena kanker. Ekstrak temulawak sangat dianjurkan untuk dikonsumsi guna mencegah penyakit hati, termasuk hepatitis B yang menjadi salah satu factor resiko timbulnya kanker hati. Disamping itu, juga terbukti bisa menurunkan kadar colesterol dalam darah dan sel hati. Semua kasiat itu berkat adanya kandungan kurkumin, yakni zat yang berguna untuk menjaga dan menyehatkan hati atau lever atau istilah medisnya hepatoprotektor. (Hadi, 1985). Tanaman khas Indonesia satu ini memiliki potensi yang luar biasa untuk dikembangkan sebagai tanaman obat. Bahkan konon, tanaman ini memiliki keunggulan setara dengan ginseng Korea. Tidak heran, banyak orang menganggap, temulawak sebagai ginsengnya Indonesia.

Tanaman obat jenis temulawak ternyata dapat mencegah terjadinya berbagai berbagai macam penyakit seperti kolesterol, jantung koroner, stroke dan rematik. Karena temulawak mengandung senyawa aktif kurkumin yang mempunyai aktifitas sebagai antioksidan dan imunostimulator / imunomodulator. Aktivitas imonomodulator dari kurkumin dapat meningkatkan daya tahan tubuh terhadap serangan penyakit sehingga tidak mudah sakit. Kurkuminnoid sebagai sekumpulan senyawa yang terdapat dalam temulawak telah terbukti secara cepat dapat menurunkan kadar SGPT dan SGOT pada penderita hepatitis (Sampurno, 2005).

Masyarakat dianjurkan tidak menkonsumsi temulawak melebihi 1 ons per hari karena dikawatirkan akan menimbulkan efek samping. Masyarakat dianjurkan mengkonsumsi 
temulawak tiga kali sehari dengan takaran 1/3 ons untuk sekali minum (Kerti, 2005).

\section{Kandungan Temulawak}

Kandungan Zat yang terdapat pada rimpang temulawak terdiri atas pati, abu, serat, dan minyak atsiri. Temulawak mengandung zat kuning yang disebut kurkumin dan minyak atsiri. Minyak atsirinya mengandung phelandrin, kamfer, borneol, xanthorrhozol, tumerol dan sineal. Berkat kandungan kurkukmin dan minyak atsiri tadi diduga penyebab berkashiatnya temulawak (Susilo, 2005).

Rimpang temulawak segar mengandung air sekitar $75 \%$. Selain itu mengandung minyak atsiri, lemak (fixed oil), zat warna, protein, resin, selulosa, pati, mineral zat-zat penyebab rasa pahit (Afifah, 2003). Menurut Sumiati (1997), rimpang temulawak dengan kadar air $10 \%$ memiliki komposisi yang terdiri atas pati, lemak, kurkukmin, serat kasar, protein, mineral dan minyak atsiri.

Komposisi rimpang temulawak kering dapat dilihat pada Tabel 2.

\section{Tabel 2. Komposisi Rimpang} Temulawak Kering (kadar air $10 \%$ )

\begin{tabular}{|l|c|}
\hline \multicolumn{1}{|c|}{ Komposisi } & Kadar (\%) \\
\hline Pati & 58.24 \\
Lemak (fixed oil) & 12.10 \\
Minyak atsiri & 4.90 \\
Abu & 4.90 \\
Mineral & 4.29 \\
Serat kasar & 4.20 \\
Protein & 2.90 \\
Kurkumin & 1.55 \\
\hline
\end{tabular}

Sumber : Sumiati (1997)
Menurut Sidik,

(1999), menyatakan bahwa rimpang temulawak kering mengandung $12 \%$ kadar air, 7 - $30 \%$ minyak atsiri, 37 - $61 \%$ karbohidrat dan 1 - $4 \%$ kurkumin. Minyak atsiri temulawak terdiri dari 40 komponen yang sebagian besar terdiri dari kurkumin 41,4 \% dan xanthorrhizol 21,5\% Kedua zat tersebut merupakan ciri khas minyak atsiri temulawak

\section{Antioksidan}

Beberapa

penelitian menunjukkan bahwa ekstrak temulawak ternyata mempunyai efek antioksidan. Sidik, (1999) mengukur antioksidan dari jenis rimpang temu-temuan dengan metoda Tiosianat dan metoda Tiobarbituric Acid (TBA) dalam sistem air-alkohol. Hasil penelitian menunjukkan bahwa aktivitas antioksidan ekstrak temulawak ternyata lebih besar dibandingkan dengan aktivitas tiga jenis kurkuminoid diperkirakan terdapat dalam temulawak. Jadi, diduga ada zat lain selain ketiga kurkuminoid tersebut yang mempunyai efek antioksidan.

Berikut ini beberapa hasil penelitian tentang zat aktif kurkumin yang terdapat dalam tumbuhan Kurkuma jenis lainnya. Dilaporkan bahwa secara invitro, efek antioksidan terjadi karena kurkumin berlaku sebagai penangkap oksigen bebas dan hidroksil bebas. Majeed, (1995) menyatakan bahwa kurkumin lebih aktif dibandingkan dengan vitamin $\mathrm{E}$, beta karotin, asam lipoat, dsb. Selanjutnya 
dibuktikan bahwa gugus fenol, metoksil, 1,3 diketon dan enolisable stiril keton mampunyai kontribusi yang nyata pada sifat antioksidan kurkumin. Aktivitas antioksidan temulawak segar lebih tinggi dibandingkan temulawak bubuk sebelum dilakukan penyimpanan masing-masing $57,10 \%$ dan $43,10 \%$ kedua bentuk temulawak tersebut memiliki aktivitas antioksidan lebih tinggi dibandingkan antioksidan sintesis BHT $1 \%$ sebesar $34,49 \%$. Setelah penyimpanan selama 15 hari, temulawak segar dengan penyimpanan 5 hari mempunyai aktivitas antioksidan tertinggi sedangkan temulawak bubuk dengan lama penyimpanan 15 hari memiliki aktivitas terendah masingmasing sebesar $51,37 \%$ dan $16,22 \%$ (Sugiarto, 2004).

\section{Dekstrin}

Dekstrin merupakan
polisakarida yang dihasilkan dari
hidrolisis pati yang diatur oleh enzim-
enzim tertentu atau hidrolisis oleh
asam berwarna putih sampai kuning. Pada pembuatan dekstrin, rantai panjang pati mengalami pemutusan oleh enzim atau asam menjadi dekstrin dengan molekul yang lebih pendek, yaitu 6-10 unit glukosa, dengan rumus molekul $\left(\mathrm{C}_{6} \mathrm{H}_{10} \mathrm{O}_{5}\right)$ n. Berkurangnya panjang rantai menyebabkan terjadinya perubahan sifat dari pati yang tidak larut dalam air menjadi dekstrin yang mudah larut dalam air, memiliki kekentalan lebih rendah dibandingkan pati (Reynold, 1982).
Arief, (1987), mengemukakan bahwa struktur molekul dekstrin berbentuk spiral, sehingga molekulmolekul flavor yang terperangkap di dalam struktur spiral helix. Dengan demikian penambahan dekstrin dapat menekan kehilangan komponen volatile selama proses pengolahan.

Dekstrin mempunyai viskositas yang relatif rendah, sehingga pemakaian dalam jumlah banyak masih diijinkan. Hal ini justru akan menguntungkan jika pemakaian dekstrin ditujukan sebagai bahan pengisi (filler) karena dapat meningkatkan berat produk yang dihasilkan (Warsiki, 1995).

Dekstrin dapat digunakan pada proses enkapsulasi, untuk melindungi senyawa volatile, melindungi senyawa yang peka terhadap oksidasi atau panas, karena molekul dari dekstrin stabil terhadap panas dan oksidasi . Dekstrin dapat melindungi stabilitas flavor selama pengeringan dengan menggunakan spray dryer (Suparti, 2000).

Warsiki,

(1995), mengemukakan bahwa kenaikan konsentrasi dekstrin dari 5-15\% akan meningkatkan rendemen, densitas kamba, penurunan kadar air, total padatan terlarut serta gula pereduksi tepung instan sari buah nanas. Wijaya, (1995) dalam Suprapti (2000), menyarankan penggunaan dekstrin sebesar $1,5 \%$ pada pembuatan pewarna bubuk dari daun suji dan daun pandan. Konsentrasi dekstrin 12,5 \% akan memberikan perlakuan terbaik pada 
pembuatan bubuk sari buah sirsak menggunakan metode foam-mat drying (Suryanto, 2000).

\section{Effervescent}

Garam "effervescent" merupakan garam atau serbuk kasar sampai kasar sekali mengandung unsur obat dalam campuran kering biasanya terdiri dari bahan obat, asam tartrat, asam sitrat, dan sodium bikarbonat (Agatha, 2006).

Menurut Ansel (1989), granula adalah gumpalan-gumpalan partikel kecil yang dibuat dengan melembabkan serbuk yang diinginkan lalu melewatkannya pada celah ayakan dengan ukuran lubang sesuai dengan ukuran granula yang dihasilkan.

Reaksi yang terjadi pada pelarutan "effervescent" adalah reaksi antara senyawa asam dan senyawa karbonat untuk menghasilkan gas karbondioksida yang memberikan efek "sparkle" atau rasa seperti air soda. Reaksi ini dikehendaki terjadi secara spontan ketika "effervescent" dilarutkan dalam air. Ansel (1989), menambahkan, larutan dengan karbonat yang dihasilkan menutupi rasa garam atau rasa yang tidak diinginkan dari zat obat. Formula garam "effervescent" resmi yang ada unsur pembentuk "effervescent" terdiri dari 53\% sodium karbonat, 28\% asam tartrat, dan 19\% asam sitrat.

Minuman dalam bentuk serbuk ini memiliki keunggulan yaitu kestabilan produk dan massanya lebih kecil serta bisa memenuhi permintaan dalam skala yang besar (Susilo, 2005).

\section{Natrium Bikarbonat}

Senyawa karbonat yang banyak digunakan dalam formulasi "effervescent" adalah garam karbonat kering karena kemampuannya menghasilkan karbondioksida. Garam karbonat tersebut antara lain Nabikarbonat, Na-karbonat, K-bikarbonat, Na-seskuikarbonat dan lain-lain. Nabikarbonat $\left(\mathrm{NaHCO}_{3}\right)$ dipilih sebagai senyawa karbondioksida dalam sistem "effervescent" karena harganya murah dan bersifat larut sempurna dalam air. Ansel (1989), menambahkan bahwa Na-bikarbonat bersifat non higroskopis dan tersedia secara komersial mulai dari bentuk bubuk sampai bentuk granular dan mampu menghasilkan 52\% karbondioksida.

Na-Bikarbonat

$\left(\mathrm{NaHCO}_{3}\right)$ merupakan serbuk kristal berwarna putih yang mampu menghasilkan karbondioksida. Na-bikarbonat memiliki berat molekul 84,01 (tiap gramnya mengandung 11,9 mmol natrium), Na-bikarbonat anhidrat terkonversi pada suhu $250-300^{\circ} \mathrm{C}$, pada $\mathrm{RH}$ di atas $85 \%$ akan cepat menyerap air dari lingkungannya dan menyebabkan dikomposisi dengan hilangnya karbondioksida dapat mengalami dekomposisi karena adanya panas yaitu pada suhu diatas $120^{\circ} \mathrm{C}$ (Reynolds 1982)

Na-Bikarbonat sering disebut sebagai soda kue, terdapat dua macam soda kue yaitu soda kue dengan aktifitas cepat (aktifitas tinggi) dan soda kue dengan aktifitas lambat (aktifitas ganda). Perbedaan antara keduanya 
adalah pada mudah tidaknya komponen asam larut dalam air dingin. Untuk produk-produk "effervescent" digunkan soda kue dengan aktifitas cepat karena memiliki kelarutan yang tinggi dalam air dingin, sehingga pelepasan karbondioksidanya juga cepat (Winarno, 1997). Sedangkan soda kue dengan aktifitas lambat banyak digunakan sebagai bahan pengembang dalam adonan roti atau biskuit.

Pada pembuatan "effervescent" temulawak yang dilakukan oleh Zuhroh (2001), penggunaan Na-bikarbonat 505 merupakan hasil yang terbaik. Wardiningrum (2001) menggunakan Na-bikarbonat $32 \%$ pada pembuatan "effervescent" mengkudu.

\section{Asam Sitrat}

Asam sitrat adalah asam dengan 3 gugus karboksil, berbentuk granula atau bubuk putih, tidak berbau dan meniliki karakteristik rasa asam, dengan rumus $\mathrm{C}_{6} \mathrm{H}_{8} \mathrm{O}_{7}$.

Asam sitrat merupakan asidulan pangan yang mempunyai fungsi bervariasi. Industri makanan dan minuman kebanyakan mengkonsumsi asidulan untuk mempertegas flavour dan warna. Hui (1992), lebih lanjut menyebutkan fungsi lain asam sitrat adalah mengontrol keasaman dengan beberapa alasan. Pengontrolan $\mathrm{pH}$ yang tepat akan mempercepat pertumbuhan mikroba dan bertidak sebagai pengawet serta membantu zat antioksidan terjadinya reaksi pencoklatan. Jumlah asam sitrat yang ditanbahkan pada minuman tidak berkarbonasi tergantung flavour

produk dengan mempertimbangkan hasil evaluasi kesukaan konsumen.

Asam sitrat digunakan sebagai asidulan pertama dalam minuman terkarbonasi dan minuman bubuk yang memberikan rasa jeruk yang tajam. Asam sitrat yang digunakan dalam "effervescent" umumnya dalam bentuk monohidrat digunakan sebagai sumber asam dalam pembuatan serbuk atau tablet "effervescent" karena memiliki kelarutan yang tinggi dalam air dingin, mudah didapat dalam bentuk granular atau serbuk (Reynold, 1982)..

Pada pembuatan serbuk "effervescent" beras kencur, Husna (2003) menyimpulkan bahwa penggunaan asam sitrat 50\% memberikan hasil yang terbaik. Wardiningrum (2001), menyimpulkan bahwa penggunaan asam sitrat 32\% memberikan hasil terbaik pada pembuatan "effervescent" mengkudu.

\section{Aspartam}

Aspartam adalah dieptil metil ester yang terdiri dari dua asam amino, yaitu fenil alanin dan asam aspartat. Senyawa ini mudah larut dalam air dan sedikit terlarut dalam alkohol dan tidak larut dalam lemak atau minyak (Reynolds, 1982).

Aspartam memiliki rasa manis 160 sampai 200 kali sukrosa, tidak ada rasa pahit atau "after teste" yang serinng terdapat pada pemanis buatan. Satu gram aspartam setara dengan 200 gram gula. Aspartam paling stabil pada 
suasana asam lemah yaitu antara $\mathrm{pH} 3-5$ pada suhu $25^{\circ} \mathrm{C}$ (Anonymous 2002).

Aspartam terdekomposisi jika mendapat perlakuan panas sehingga intensitas rasa manisnya berkurang . Aspartam dapat digunakan untuk semua jenis gula rendah kalori misalnya untuk kegemukan dan diabetes karena kandungan kalorinya yang rendah dan tidak menyebabkan kelainan gigi seperti karies. Penelitian toksikologi aspartam oleh "Joint Expert Committee for Food Additives" dan WHO menetapkan nilai "Acceptable Daily Intake" (AID) untuk aspartam sebesar $40 \mathrm{mg} /$ hari (Susilo.2005).

\section{METODE PENELITIAN}

\section{Tempat dan Waktu}

Penelitian dilaksanakan di Laboratorrium Pengolahan Hasil Balai Besar Diklat Tanaman Pangan dan Tanaman Obat, Laboratorium Pengolahan Hasil Pertanian Fakultas Teknologi Pertanian UNIBRAW Malang, Laboratorium MIPA UNIBRAW Malang. Dilaksanakan pada bulan April sampai dengan Juli 2007.

\section{Metode Penelitian}

Rancangan percobaan yang digunakan dalam Penelitian Tahap I (Pembuatan Sari Temulawak) dan Penelitian Tahap II (Pembuatan Serbuk Effervescent Temulawak) menggunakan Rancangan Acak Kelompok (RAK). Perlakuan terdiri dari dua faktor, masing-masing faktor terdiri dari tiga level dengan 3 kali ulangan.

\section{Variabel Pengamatan Penelitian Tahap I}

Uji aktivitas antioksidan, Kadar Air, Gula Reduksi, Intensitas Warna, Rendemen, pH, Reabsorpsi dan Uji organoleptik

\section{Variabel Pengamatan Penelitian Tahap II}

Uji aktivitas antioksidan, Intensitas Warna, Kadar Air, Kelarutan Kecerahan, pH, Gula Reduksi, dan Uji organoleptik.

\section{Analisa Data}

Data yang didapat dari hasil pengamatan setelah perlakuan penelitian tahap I dan tahap II pada masing-masing variabel dimasukkan ke dalam tabel untuk dilakukan analisa Inferensial dengan uji $\mathrm{F}$ metode Sidik Ragam (ANOVA), jika kombinasi perlakuan terjadi interaksi (diterima $\mathrm{H}_{1}$ ), maka dilakukan uji lanjut dengan uji perbandingan Duncan $1 \%$

Data hasil organoleptik dikaji menggunakan uji kesukaan terhadap warna, rasa, bau dan tektur yang menggunakan Uji Friedman. Sedangkan pemilihan perlakuan terbaik menggunakan metode Indeks efektifitas

\section{HASIL DAN PEMBAHASAN}

\section{Penelitian Tahap I Sari Temulawak}

Pengamatan pada penelitian 
Tahap I meliputi kadar air, gula reduksi, aktivitas antioksidan, rendemen, $\mathrm{pH}$, reabsorpsi, kecerahan, intensitas warna merah (a+), intensitas warna kuning (b+) serta uji organoleptik yang terdiri dari rasa, warna dan aroma.

\section{Kadar Air}

Hasil analisis sidik ragam (Lampiran 13) menunjukkan bahwa adanya perbedaan konsentrasi dekstrin dan suhu pengering serta interaksi antar perlakuan memberikan pengaruh sangat nyata $(\alpha=0,01)$ terhadap kadar air serbuk sari temulawak. Rerata nilai kadar air pada berbagai kombinasi perlakuan ditunjukkankan pada Tabel 3.

Tabel 3. Rerata Kadar Air (\%) Serbuk Sari Temulawak pada Berbagai Kombinasi Perlakuan Konsentrasi Dekstrin dan Suhu Pengering

\begin{tabular}{|c|c|c|c|}
\hline $\begin{array}{c}\text { Konsentra } \\
\text { si Dekstrin } \\
(\boldsymbol{\%})\end{array}$ & $\begin{array}{c}\text { Suhu } \\
\text { Pengerin } \\
\mathbf{g}\left({ }^{\circ} \mathbf{C}\right)\end{array}$ & $\begin{array}{c}\text { Kadar } \\
\text { Air }(\%)\end{array}$ & $\begin{array}{c}\text { DMRT } \\
(\boldsymbol{\alpha}=\mathbf{0 , 0 1})\end{array}$ \\
\hline & 40 & $13,88^{\mathrm{g}}$ & - \\
10 & 50 & $13,13^{\mathrm{f}}$ & 0,30 \\
& 60 & $12,37^{\mathrm{e}}$ & 0,29 \\
\hline & 40 & $12,11^{\mathrm{de}}$ & 0,29 \\
15 & 50 & $11,80^{\mathrm{c}}$ & 0,29 \\
& 60 & $10,32^{\mathrm{b}}$ & 0,28 \\
\hline & 40 & $11,98^{\mathrm{cd}}$ & 0,29 \\
20 & 50 & $10,11^{\mathrm{b}}$ & 0,27 \\
& 60 & $8,54^{\mathrm{a}}$ & 0,26 \\
\hline
\end{tabular}

Keterangan : Angka rerata yang diikuti dengan huruf yang sama pada kolom yang sama tidak berbeda nyata pada uji Duncan $1 \%$

Rerata kadar air serbuk sari temulawak terendah didapatkan dari perlakuan penambahan konsentrasi dekstrin $20 \%$ dengan suhu pengering $60^{\circ} \mathrm{C}$ dengan nilai terendahnya adalah $8,54 \%$, sedangkan rerata kadar air serbuk sari temulawak tertinggi diperoleh dari perlakuan penambahan konsentrasi dekstrin $10 \%$ dengan suhu pengering $\quad 40^{\circ} \mathrm{C}$ dengan nilai tertingginya adalah $13,88 \%$. Semakin tinggi penambahan konsentrasi dekstrin maka kadar air dari serbuk sari temulawak akan semakin rendah dan semakin tinggi suhu pengeringan maka kadar air serbuk sari temulawak juga akan semakin rendah.

Penambahan konsentrasi dekstrin akan menurunkan kadar air serbuk sari temulawak. Hal ini terjadi karena pada konsentrasi bahan pengisi yang ditambahkan semakin banyak atau lebih tinggi maka perbandingan konsentrasi ekstrak sari temulawak cair akan lebih rendah sehingga kadar air dari bahan akan semakin rendah. Selain itu adanya penambahan konsentrasi bahan pengisi dekstrin yang semakin meningkat akan mengikat air yang ada pada sari temulawak sehingga kadar airnya semakin rendah. Menurut Warsiki (1995), mengemukakan bahwa kenaikan konsentrasi dekstrin dari 5$15 \%$ akan menurunkan kadar air, meningkatkan rendemen dan densitas kamba tepung instan sari buah nanas. Ditambahkan oleh Al Kahtani dan Hassan (1990) dalam Puspaningrum (2003), penambahan bahan pengisi akan meningkatkan jumlah total padatan dalam bahan sehingga jumlah air pada bahan yang dikeringkan akan semakin sedikit. 
Peningkatan suhu pengering juga akan menurunkan kadar air serbuk sari temulawak, karena semakin tinggi suhu pengering maka kadar air bahan akan semakin rendah ini disebabkan karena kecepatan pengeringan akan semakin meningkat dengan semakin meningkatnya suhu pengering. Desrosier (1988) menyatakan faktorfaktor yang mempengaruhi kecepatan pengeringan produk pangan beberapa diantaranya adalah suhu pengeringan yang digunakan, lama pengeringan (waktu), metode pengeringan dan sifat dan bentuk bahan.

Intensitas Warna (Kecerahan/L*, Kemerahan/a* dan Kekuningan/b*)

Hasil analisis sidik ragam Intensitas warna (kecerahan, kemerahan, kekuningan) menunjukkan bahwa perlakuan konsentrasi dekstrin dan suhu pengering serta interaksi antar perlakuan memberikan pengaruh sangat nyata $(\alpha=0,01)$ terhadap ketiganya serbuk sari temulawak. Rerata kecerahan serbuk sari temulawak yang dihasilkan berkisar antara 54,00-60,10. Rerata kemerahan serbuk sari temulawak yang dihasilkan berkisar antara 13,23-15,45. Rerata kekuningan serbuk sari temulawak yang dihasilkan berkisar antara 42,37-46,53.

Tingkat kecerahan serbuk sari temulawak terendah didapatkan dari perlakuan konsentrasi dekstrin $20 \%$ dan suhu pengering $60^{\circ} \mathrm{C}$ dengan nilai 54,00 dan tertinggi adalah dari perlakuan konsentrasi dekstrin $10 \%$ dan suhu pengering $40^{\circ} \mathrm{C}$ dengan nilai kecerahan 60,10 . Penambahan konsentrasi dekstrin semakin tinggi maka tingkat kecerahan serbuk sari temulawak juga semakin meningkat, karena warna dekstrin cenderung putih sehingga dengan adanya penambahan dekstrin yang banyak maka tingkat kecerahan serbuk sari temulawak juga semakin meningkat. Tingkat kemerahan dan kekuningan serbuk sari temulawak terendah didapatkan dari perlakuan yang sama yaitu konsentrasi dekstrin $10 \%$ dan suhu pengering $40^{\circ} \mathrm{C}$ dengan nilainya berturut-turut adalah 13,23 (a*) dan 42,37 (b*). Sedangkan nilai tertinggi untuk parameter tingkat kemerahan dan kekuningan sari temulawak juga didapatkan dari perlakuan yang sama yaitu konsentrasi dekstrin $20 \%$ dan suhu pengering $60^{\circ} \mathrm{C}$ dengan nilainya berturut-turut 15,45 (a*) dan 46,53 (b*). Semakin tinggi konsentrasi dekstrin yang ditambakkan dan juga dengan semakin meningkatnya suhu pengering maka tingkat kemerahan dan kekuningan serbuk sari temulawak juga semakin meningkat.

Semakin tinggi konsentrasi dekstrin, tingkat kecerahan $\left(\mathrm{L}^{*}\right)$ serbuk sari temulawak cenderung semakin tinggi (cerah), sedangkan tingkat kemerahan/a* dan tingkat kekuningan/b* serbuk sari temulawak cenderung semakin rendah atau dapat dikatakan bahwa semakin tinggi konsentrasi dekstrin maka warna serbuk yang dihasilkan cenderung semakin putih dan sedikit kuning-kemerahan. Hal ini disebabkan karena konsentrasi 
dekstrin yang ditambahkan semakin banyak menyebabkan kecerahannya semakin cerah dan agak sedikit kuning. Wara kuning dari bubuk sari temulawak disebabkan karena kandungan kurcumin dari remulawak. Karena dari bubuk dekstrin sendiri berwarna putih, oleh karena itu dengan semakin banyaknya konsentrasi yang ditambahkan maka kecerahan serbuk sari temulawak semakin meningkat dan warna kuning dari sari temulawak semakin rendah. Semakin tinggi suhu pengering maka kecerahan/L* serbuk sari temulawak semakin turun dan tinggkat kekuningan dan kemerahan semakin meningkat. Ini disebakan karena dengan adanya peningkatan suhu pengering dari $40^{\circ} \mathrm{C}$ ke $50^{\circ} \mathrm{C}$ dan $60^{\circ} \mathrm{C}$ akan lebih cepat memacu proses pencoklatan nonenzimatis (reaksi maillard). Pada pengeringan suhu $60^{\circ} \mathrm{C}$ akan cepat memacu proses pencoklatan pada bubuk sari temulawak sehingga dihasilkan warna lebih coklat kekuningan daripada pengeringan suhu $40^{\circ} \mathrm{C}$ dan $50^{\circ} \mathrm{C}$.

Labuza (1982) menyatakan bahwa suhu mempunyai pengaruh yang lebih besar terhadap pencoklatan nonenzimatis, dimana setiap kenaikan suhu sebesar $10^{\circ} \mathrm{C}$ kecepatan proses pencoklatan meningkat antara 4-8 kali. Menurut Desrosier (1988), Yeo and Shibamoto (1991) menyatakan bahwa suhu tinggi menyebabkan reaksi pencoklatan dari gula dan asam amino (reaksi maillard) makin meningkat yang berpengaruh terhadap warna dan flavor yang tidak diinginkan pada bahan makanan.

\section{Reabsorpsi}

Hasil analisis sidik ragam reabsorpsi menunjukkan bahwa konsentrasi dekstrin dan suhu pengering serta interaksi antar perlakuan memberikan pengaruh sangat nyata $(\alpha$ $=0,01)$ terhadap reabsorpsi serbuk sari temulawak. Rerata reabsorpsi pada berbagai kombinasi perlakuan konsentrasi dekstrin dan suhu pengering ditunjukkan pada Tabel 4.

Tabel 4. Rerata Reabsorpsi Serbuk Sari temulawak pada Berbagai Kombinasi Perlakuan Konsentrasi Dekstrin dan Suhu Pengering

\begin{tabular}{|c|c|c|c|}
\hline $\begin{array}{c}\text { Konsentr } \\
\text { asi } \\
\text { Dekstrin } \\
(\boldsymbol{\%})\end{array}$ & $\begin{array}{c}\text { Suhu } \\
\text { Pengeri } \\
\text { ng }\left({ }^{\circ} \mathbf{C}\right)\end{array}$ & $\begin{array}{c}\text { Reabsorp } \\
\text { si }(\%)\end{array}$ & $\begin{array}{c}\text { DMRT } \\
(\boldsymbol{\alpha}=\mathbf{0 , 0} \\
\mathbf{1})\end{array}$ \\
\hline \multirow{2}{*}{10} & 40 & $1,28^{\mathrm{a}}$ & 0,16 \\
& 50 & $2,46^{\mathrm{bc}}$ & 0,18 \\
& 60 & $3,35^{\mathrm{d}}$ & 0,18 \\
\hline & 40 & $2,30^{\mathrm{b}}$ & 0,17 \\
& 50 & $2,67^{\mathrm{c}}$ & 0,18 \\
& 60 & $3,96^{\text {ef }}$ & - \\
\hline & 40 & $2,36^{\mathrm{bc}}$ & 0,17 \\
& 50 & $2,78^{\mathrm{cd}}$ & 0,18 \\
& 60 & $4,07^{\mathrm{f}}$ & 0,17 \\
\hline
\end{tabular}

Keterangan : Angka rerata yang diikuti dengan huruf yang sama pada kolom yang sama tidak berbeda nyata pada uji Duncan 1\%

Rerata reabsorpsi serbuk sari temulawak terendah didapatkan dari perlakuan penambahan konsentrasi dekstrin $10 \%$ dengan suhu pengering $40^{\circ} \mathrm{C}$ dengan nilai terendahnya adalah $1,28 \%$, sedangkan rerata reabsorpsi serbuk sari temulawak tertinggi diperoleh dari perlakuan penambahan 
konsentrasi dekstrin $20 \%$ dengan suhu pengering $60^{\circ} \mathrm{C}$ dengan nilai tertingginya adalah $4,07 \%$. Semakin tinggi penambahan konsentrasi dekstrin maka reabsorpsi serbuk sari temulawak akan semakin tinggi dan semakin tinggi suhu pengering maka reabsorpsi serbuk sari temulawak juga akan semakin tinggi.

Nilai reabsorpsi serbuk sari temulawak cenderung naik dengan semakin tingginya konsentrasi dekstrin. Hal ini disebabkan semakin tinggi konsentrasi bahan pengisi dalam hal ini dekstrin yang ditambahkan maka gugus hidroksil yang terkandung dalam serbuk sari temulawak akan semakin banyak dan reabsorpsinya juga akan semakin tinggi. Gugus hidroksil dalam jumlah banyak dapat meningkatkan kemampuan dalam meningkatkan air dalam senyawa tersebut (Alexander, 1992 dalam Puspaningrum, 2003).

\section{pH}

Hasil analisis sidik ragam $\mathrm{pH}$ (Lampiran 18) menunjukkan bahwa konsentrasi dekstrin dan suhu pengering serta interaksi antar perlakuan memberikan pengaruh sangat nyata $(\alpha$ $=0,01)$ terhadap $\mathrm{pH}$ serbuk sari temulawak. Rerata $\mathrm{pH}$ pada berbagai kombinasi perlakuan konsentrasi dekstrin dan suhu pengering ditunjukkan pada Tabel 5.

\section{Tabel 5 Rerata pH Serbuk Sari temulawak pada Berbagai Kombinasi Perlakuan Konsentrasi Dekstrin dan Suhu Pengering}

\begin{tabular}{|c|c|c|c|}
\hline $\begin{array}{l}\text { Konsentr } \\
\text { asi } \\
\text { Dekstrin } \\
(\%)\end{array}$ & $\begin{array}{c}\text { Suhu } \\
\text { Pengerin } \\
\text { g }\left({ }^{\circ} \mathrm{C}\right)\end{array}$ & pH & $\begin{array}{c}\text { DMRT } \\
(\alpha=0,01 \\
)\end{array}$ \\
\hline 10 & $\begin{array}{l}40 \\
50 \\
60\end{array}$ & $\begin{array}{c}6,03^{\mathrm{d}} \\
5,67^{\mathrm{ab}} \\
5,77^{\mathrm{c}}\end{array}$ & $\begin{array}{c}- \\
0,13 \\
0,13\end{array}$ \\
\hline 15 & $\begin{array}{l}40 \\
50 \\
60\end{array}$ & $\begin{array}{c}5,63^{\mathrm{a}} \\
5,67^{\text {ab }} \\
\mathrm{c} \\
5,70^{\mathrm{bc}}\end{array}$ & $\begin{array}{l}0,12 \\
0,13 \\
0,13\end{array}$ \\
\hline 20 & $\begin{array}{l}40 \\
50 \\
60\end{array}$ & $\begin{array}{c}5,57^{\mathrm{a}} \\
5,63^{\mathrm{ab}} \\
5,67^{\mathrm{ab}} \\
\mathrm{c}\end{array}$ & $\begin{array}{l}0,12 \\
0,13 \\
0,13\end{array}$ \\
\hline
\end{tabular}

Keterangan : Angka rerata yang diikuti dengan huruf yang sama pada kolom yang sama tidak berbeda nyata pada uji Duncan 1\%

Rerata $\mathrm{pH}$ serbuk sari temulawak tertinggi didapatkan dari kombinasi perlakuan konsentrasi dekstrin $10 \%$ dan suhu pengering $40^{\circ} \mathrm{C}$ dengan nilai 6,03 , sedangkan $\mathrm{pH}$ nilai terendah didapatkan dari kombinasi perlakuan konsentrasi dekstrin $20 \%$ dan suhu pengering $40^{\circ} \mathrm{C}$ dengan nilai 5,57.

Semakin tinggi konsentrasi dekstrin yang ditambahkan maka nilai $\mathrm{pH}$ serbuk sari temulawak semakin rendah. Hal ini diduga karena sisa asam pada dekstrin akibat proses hidrolisis dengan asam atau enzim. Thomas and Alusell (1997) menyatakan bahwa dekstrin an produk sejenisnya dibuat dengan hidrolisis pati dengan pemanasan dan asam atau enzim. Oleh karena itu semakin tinggi konsentrasi bahan pengisi yang ditambahkan dalam ini adalah dekstrin maka sisa asam akan semakin banyak menyebabkan nilai $\mathrm{pH}$ serbuk sari temulawak akan semakin menurun. 


\section{Rendemen}

Hasil analisis sidik ragam rendemen menunjukkan bahwa konsentrasi dekstrin dan suhu pengering serta interaksi antar perlakuan memberikan pengaruh sangat nyata $(\alpha$ $=0,01)$ terhadap rendemen serbuk sari temulawak. Rerata rendemen pada berbagai kombinasi perlakuan konsentrasi dekstrin dan suhu pengering ditunjukkan pada Tabel 6 .

Tabel 6. Rerata Rendemen (\%) Serbuk Sari temulawak pada Berbagai Kombinasi Perlakuan Konsentrasi Dekstrin dan Suhu Pengering

\begin{tabular}{|c|c|c|c|}
\hline $\begin{array}{c}\text { Konsentr } \\
\text { asi } \\
\text { Dekstrin } \\
(\boldsymbol{\%})\end{array}$ & $\begin{array}{c}\text { Suhu } \\
\text { Pengeri } \\
\text { ng }\left({ }^{\circ} \mathbf{C}\right)\end{array}$ & $\begin{array}{c}\text { Rendem } \\
\text { en }(\%)\end{array}$ & $\begin{array}{c}\text { DMRT } \\
(\mathbf{\alpha = 0 , 0} \\
\mathbf{1})\end{array}$ \\
\hline & 40 & $14,02^{\mathrm{a}}$ & 0,38 \\
10 & 50 & $15,79^{\mathrm{b}}$ & 0,40 \\
& 60 & $16,90^{\mathrm{c}}$ & 0,41 \\
\hline & 40 & $16,95^{\mathrm{c}}$ & 0,41 \\
15 & 50 & $18,10^{\mathrm{d}}$ & 0,42 \\
& 60 & $20,09^{\mathrm{e}}$ & 0,42 \\
\hline & 40 & $22,29^{\mathrm{f}}$ & 0,43 \\
& 50 & $24,63^{\mathrm{g}}$ & 0,43 \\
& 60 & $26,21^{\mathrm{h}}$ & - \\
\hline
\end{tabular}

Keterangan : Angka rerata yang diikuti dengan huruf yang sama pada kolom yang sama tidak berbeda nyata pada uji Duncan 1\%

Rerata rendemen serbuk sari temulawak terendah didapatkan dari perlakuan penambahan konsentrasi dekstrin $10 \%$ dengan suhu pengering $40^{\circ} \mathrm{C}$ dengan nilai terendahnya adalah $14,025 \%$, sedangkan rerata rendemen serbuk sari temulawak tertinggi diperoleh dari perlakuan penambahan konsentrasi dekstrin 20\% dengan suhu pengering $\quad 60^{\circ} \mathrm{C}$ dengan nilai tertingginya adalah 26,21\%. Semakin tinggi penambahan konsentrasi dekstrin maka rendemen serbuk sari temulawak akan semakin tinggi dan semakin tinggi suhu pengering maka rendemen serbuk sari temulawak juga akan semakin tinggi.

Nilai rendemen serbuk sari temulawak cenderung naik dengan semakin tingginya konsentrasi dekstrin. Hal ini karena semakin tinggi konsentrasi bahan pengisi dalam hal ini dekstrin yang ditambahkan maka konsentrasi sari temulawak cair semakin sedikit. Kenaikan konsentrasi dekstrin yang ditambahkan dapat meningkatkan rendemen dan densitas kamba tepung instan sari buah nanas (Warsiki, 1995).

Rendemen serbuk sari temulawak semakin meningkat dengan meningkatnya konsentrasi bahan pengisi yang semakin besar. Hal ini diduga semakin banyak bahan pengisi yang ditambahkan maka jumlah total padatan dalam serbuk sari temulawak semakin tinggi sehingga meningkatkan jumlah rendemen. Master (1979) menyatakan bahwa semakin tinggi total padatan pada bahan yang dikeringkan maka rendemen yang dihasilkan juga akan semakin tinggi.

\section{Gula Reduksi}

Hasil analisis sidik ragam gula reduksi diketahui terdapat pengaruh sangat nyata $\quad(\alpha=0,01)$ antara konsentrasi dekstrin, suhu pengering 
dan interaksi antar kedua perlakuan. Rerata nilai gula reduksi pada berbagai kombinasi perlakuan ditunjukkankan pada Tabel 7.

Tabel 7. Rerata Kadar Gula Reduksi (\%) Serbuk Sari temulawak pada Berbagai Kombinasi Perlakuan Konsentrasi Dekstrin dan Suhu Pengering

\begin{tabular}{|c|c|c|c|}
\hline $\begin{array}{c}\text { Konsentra } \\
\text { si Dekstrin } \\
(\boldsymbol{\%})\end{array}$ & $\begin{array}{c}\text { Suhu } \\
\text { Pengerin } \\
\mathbf{g}\left({ }^{\circ} \mathbf{C}\right)\end{array}$ & $\begin{array}{c}\text { Kadar } \\
\text { Gula } \\
\text { Reduks } \\
\mathbf{i}(\boldsymbol{\%})\end{array}$ & $\begin{array}{c}\text { DMRT } \\
(\boldsymbol{\alpha}=\mathbf{0 , 0 1} \\
)\end{array}$ \\
\hline \multirow{2}{*}{10} & 40 & $1,45^{\mathrm{a}}$ & 0,04 \\
& 50 & $1,56^{\mathrm{b}}$ & 0,40 \\
& 60 & $1,71^{\mathrm{cd}}$ & 0,40 \\
\hline & 40 & $1,60^{\mathrm{b}}$ & 0,40 \\
& 50 & $1,93^{\mathrm{f}}$ & 0,40 \\
& 60 & $2,16^{\mathrm{g}}$ & 0,40 \\
\hline & 40 & $1,72^{\mathrm{d}}$ & 0,40 \\
20 & 50 & $1,88^{\mathrm{e}}$ & 0,40 \\
& 60 & $2,23^{\mathrm{h}}$ & - \\
\hline
\end{tabular}

Keterangan : Angka rerata yang diikuti dengan huruf yang sama pada kolom yang sama tidak berbeda nyata pada uji Duncan $1 \%$

Rerata kadar gula reduksi serbuk sari temulawak terendah didapatkan dari perlakuan penambahan konsentrasi dekstrin $10 \%$ dengan suhu pengering $\quad 40^{\circ} \mathrm{C}$ dengan nilai terendahnya adalah $1,45 \%$, sedangkan rerata kadar gula reduksi serbuk sari temulawak tertinggi diperoleh dari perlakuan penambahan konsentrasi dekstrin 20\% dengan suhu pengering $60^{\circ} \mathrm{C}$ dengan nilai tertingginya adalah $2,23 \%$. Semakin tinggi penambahan konsentrasi dekstrin maka kadar gula reduksi dari serbuk sari temulawak akan semakin tinggi dan semakin tinggi suhu pengeringan maka kadar gula reduksi serbuk sari temulawak juga akan semakin tinggi.

Penambahan konsentrasi dekstrin akan menyebabkan peningkatan kadar gula reduksi serbuk sari temulawak, karena semakin tinggi konsentrasi dekstrin maka gugus hidroksi reaktifnya juga semakin banyak dan gugus hidroksi reaktif itu menunjukkan sifat pereduksi. Winarno (1991) menyatakan bahwa, ada tidaknya sifat pereduksi dari suatu molekul gula ditentukan oleh ada tidaknya gugus hidroksil $(\mathrm{OH})$ bebas yang reaktif.

Peningkatan suhu pengering juga akan mempengaruhi peningkatan gula reduksi dari serbuk sari temulawak. Hal ini disebakan karena semakin tinggi suhu maka pemecahan dekstrin menjadi gula-gula reduksi akan semakin banyak dan gula reduksi menunjukkan kadar dari gula reduksi.

\section{Kadar Antioksidan}

Hasil analisis sidik ragam $\mathrm{pH}$ menunjukkan bahwa konsentrasi dekstrin dan suhu pengering serta interaksi antar perlakuan memberikan pengaruh sangat nyata $(\alpha=0,01)$ terhadap kadar antioksidan serbuk sari temulawak. Rerata kadar antioksidan pada berbagai kombinasi perlakuan konsentrasi dekstrin dan suhu pengering ditunjukkan pada Tabel 8. 
Tabel 8. Rerata Kadar Antioksidan Serbuk Sari temulawak pada Berbagai Kombinasi Perlakuan Konsentrasi Dekstrin dan Suhu Pengering

\begin{tabular}{|c|c|c|c|}
\hline $\begin{array}{c}\text { Konsentr } \\
\text { asi } \\
\text { Dekstrin } \\
(\%)\end{array}$ & $\begin{array}{c}\text { Suhu } \\
\text { Pengeri } \\
\text { ng }\left({ }^{\circ} \mathbf{C}\right)\end{array}$ & $\begin{array}{c}\text { Kadar } \\
\text { Antioksid } \\
\text { an }(\%)\end{array}$ & $\begin{array}{c}\text { DMRT } \\
(\boldsymbol{\alpha = 0 , 0} \\
\mathbf{1})\end{array}$ \\
\hline \multirow{2}{*}{10} & 40 & $52,37^{\mathrm{e}}$ & 1,95 \\
& 50 & $43,67^{\mathrm{bc}}$ & 1,84 \\
& 60 & $30,23^{\mathrm{a}}$ & 1,75 \\
\hline \multirow{2}{*}{15} & 40 & $60,12^{\mathrm{g}}$ & 1,98 \\
& 50 & $54,35^{\mathrm{f}}$ & 1,96 \\
& 60 & $48,06^{\mathrm{d}}$ & 1,92 \\
\hline \multirow{2}{*}{20} & 40 & $63,13^{\mathrm{i}}$ & - \\
& 50 & $62,27^{\mathrm{hi}}$ & 1,99 \\
& 60 & $44,36^{\mathrm{c}}$ & 1,88 \\
\hline
\end{tabular}

Keterangan : Angka rerata yang diikuti dengan huruf yang sama pada kolom yang sama tidak berbeda nyata pada uji Duncan $1 \%$

Rerata kadar antioksidan serbuk sari temulawak tertinggi didapatkan dari kombinasi perlakuan konsentrasi dekstrin $20 \%$ dan suhu pengering $40^{\circ} \mathrm{C}$ dengan nilai $63,13 \%$, sedangkan kadar antioksidan terendah didapatkan dari kombinasi perlakuan konsentrasi dekstrin $10 \%$ dan suhu pengering $60^{\circ} \mathrm{C}$ dengan nilai $30,23 \%$.

Semakin meningkat konsentrasi dekstrin maka kadar antioksidan serbuk sari temulawak semakin tinggi tetapi semakin tinggi suhu pengeringan maka kadar antioksidannya semakin rendah. Konsentrasi dekstrin yang semakin banyak akan melindungi senyawa antioksidan yang ada pada serbuk sari temulawak sehingga kadar antioksidannya semakin tinggi. Fungsi bahan pengisi dekstrin akan melindungi senyawa antioksidan serbuk sari temulawak, tetapi dengan semakin meningkatnya suhu pengering akan dapat merusak struktur antioksidan sehingga kadarnya rendah.

\section{Uji Organoleptik \\ Rasa}

Hasil uji organoleptik menunjukkan bahwa rerata ranking kesukaan panelis terhadap rasa sari temulawak akibat perlakuan konsentrasi dekstrin dan suhu pengering berkisar antara 3,20-5,95.

$$
\text { Rerata nilai kesukaan }
$$
panelis terhadap rasa serbuk sari temulawak mempunyai nilai terendah 3,20 didapatkan dari kombinasi perlakuan penambahan konsentrasi dekstrin $15 \%$ dan suhu pengering $40^{\circ} \mathrm{C}$ sedangkan nilai tertinggi 5,95 didapatkan dari kombinasi perlakuan konsentrasi dekstrin $20 \%$ dan suhu pengering $50^{\circ} \mathrm{C}$.

Hasil analisis Uji Friedman menunjukkan bahwa kombinasi perlakuan konsentrasi dekstrin dan suhu pengering memberikan pengaruh nyata terhadap rerata kesukaan rasa serbuk sari temulawak. Kombinasi perlakuan terbaik tingkat kesukaan rasa diperoleh dari konsentrasi dekstrin $20 \%$ dengan suhu pengering $50^{\circ} \mathrm{C}$.

\section{Warna}

Hasil uji organoleptik menunjukkan bahwa rerata ranking kesukaan panelis terhadap warna serbuk 
sari temulawak akibat perlakuan konsentrasi dekstrin dan suhu pengering berkisar antara 4,05-5,55.

Rerata nilai kesukaan panelis terhadap warna serbuk sari temulawak mempunyai kecenderungan semakin meningkat dengan semakin meningkatnya konsentrasi dekstrin dan peningkatan suhu pengering. Rerata nilai kesukaan panelis terhadap warna terendah adalah 4,05 yaitu pada kombinasi perlakuan konsentrasi dekstrin $15 \%$ dan suhu pengering $40^{\circ} \mathrm{C}$ sedangkan rerata nilai kesukaan panelis terhadap warna tertinggi didapatkan dari kombinasi perlakuan konsentrasi dekstrin $20 \%$ dengan suhu pengering $50^{\circ} \mathrm{C}$ sebesar 5,55.

Hasil analisis Uji Friedman menunjukkan bahwa perlakuan konsentrasi dekstrin dan suhu pengering memberikan pengaruh nyata terhadap rerata kesukaan panelis terhadap warna serbuk sari temulawak. Perlakuan terbaik kesukaan panelis terhadap warna diperoleh dari konsentrasi dekstrin $20 \%$ dengan suhu pengering $50^{\circ} \mathrm{C}$.

\section{Aroma}

Hasil uji organoleptik menunjukkan bahwa rerata ranking kesukaan panelis terhadap aroma serbuk sari temulawak akibat perlakuan konsentrasi dekstrin dan suhu pengering berkisar antara 3,35-5,85.

Rerata nilai kesukaan panelis terhadap aroma serbuk sari temulawak mempunyai nilai rerata terendah sebesar 3,35 yaitu pada kombinasi perlakuan konsentrasi dekstrin $15 \%$ dan suhu pengering $50^{\circ} \mathrm{C}$, sedangkan rerata nilai kesukaan panelis terhadap aroma tertinggi didapatkan dari kombinasi perlakuan konsentrasi dekstrin $10 \%$ dan suhu pengering $60^{\circ} \mathrm{C}$ yaitu 5,85 .

Hasil analisis Uji Friedman menunjukkan bahwa kombinasi perlakuan konsentrasi dekstrin dan suhu pengering memberikan perbedaan nyata terhadap rerata kesukaan aroma panelis. Kombinasi perlakuan terbaik kesukaan aroma panelis diperoleh dari penambahan konsentrasi dekstrin $10 \%$ dengan suhu pengering $60^{\circ} \mathrm{C}$.

\section{Pemilihan Alternatif Terbaik}

Hasil perhitungan menunjukkan perlakuan terbaik pada tahap I untuk parameter fisikokimia dan organoleptik serbuk sari temulawak yaitu dari kombinasi perlakuan konsentrasi dekstrin $20 \%$ dan suhu pengering $50^{\circ} \mathrm{C}$ dengan karakteristik sebagai berikut: kadar air 10,11\%; tingkat kecerahan (L*) 55,10; tingkat kemerahan (a*) 14,56; tingkat kekuningan (b*) 44,20; rendemen 24,63\%; pH 5,63; reabsorbsi air 2,78; kadar gula reduksi $1,88 \%$ dan kadar antioksidan $62,27 \%$

Hasil perhitungan parameter organoleptik didapatkan perlakuan terbaik pada serbuk sari temulawak dengan perlakuan terbaik yang sama dengan parameter fisikokimia yaitu kombinasi perlakuan konsentrasi 
dekstrin $20 \%$ dan suhu pengering $50^{\circ} \mathrm{C}$ dengan karakteristik sebagai berikut: rerata tingkat kesukaan panelis terhadap warna 5,55; rasa 5,95 dan aroma 4,15.

\section{Penelitian Tahap II Serbuk Effervescent Temulawak}

Kadar Air

Hasil analisis sidik ragam menunjukkan bahwa adanya perbedaan konsentrasi asam sitrat dan Natrium bikarbonat serta interaksi antar perlakuan memberikan pengaruh sangat nyata $\quad(\alpha=0,01)$ terhadap kadar air serbuk effervescent temulawak. Rerata nilai kadar air pada berbagai kombinasi perlakuan ditunjukkan pada Tabel 9.

Rerata kadar air serbuk effervescent temulawak terendah didapatkan dari kombinasi perlakuan konsentrasi asam sitrat $10 \%$ dan Natrium bikarbonat $10 \%$ dengan nilai terendahnya adalah $4,86 \%$, sedangkan rerata kadar air serbuk effervescent temulawak tertinggi diperoleh dari kombinasi perlakuan konsentrasi asam sitrat $20 \%$ dan Natrium bikarbonat $20 \%$ dengan nilai tertingginya adalah $9,63 \%$. Semakin tinggi penambahan konsentrasi asam sitrat dan natrium bikarbonat maka kadar air dari serbuk effervescent temulawak akan semakin meningkat.

Perlakuan

peningkatan konsentrasi asam sitrat dan natrium bikarbonat akan meningkatkan kadar air serbuk effervescent temulawak. Hal ini terjadi karena asam sitrat dan natrium bikarbonat yang ditambahkan bersifat higroskopis (mudah menyerap uap air), sehingga dengan semakin banyak asam sitrat dan natrium bikarbonat yang ditambahkan maka kadar air serbuk effervescent temulawak akan semakin tinggi.

Tabel 9. Rerata Kadar Air (\%) Serbuk Effervescent Temulawak pada Berbagai Kombinasi Perlakuan Asam Sitrat dan Natrium Bikarbonat

\begin{tabular}{|c|c|c|c|}
\hline $\begin{array}{c}\text { Konsentra } \\
\text { si Asam } \\
\text { Sitrat (\%) }\end{array}$ & $\begin{array}{c}\text { Natrium } \\
\text { Bikarbona } \\
\mathbf{t}(\boldsymbol{\%})\end{array}$ & $\begin{array}{c}\text { Kada } \\
\text { r Air } \\
(\boldsymbol{\%})\end{array}$ & $\begin{array}{c}\text { DMRT } \\
(\boldsymbol{\alpha}=\mathbf{0 , 0 1} \\
\mathbf{)}\end{array}$ \\
\hline \multirow{2}{*}{10} & 10 & $4,86^{\mathrm{a}}$ & 0,21 \\
& 15 & $6,37^{\mathrm{b}}$ & 0,22 \\
& 20 & $7,48^{\mathrm{c}}$ & 0,22 \\
\hline \multirow{2}{*}{15} & 10 & $7,77^{\mathrm{d}}$ & 0,23 \\
& 15 & $8,02^{\mathrm{e}}$ & 0,23 \\
& 20 & $8,03^{\mathrm{e}}$ & 0,23 \\
\hline \multirow{2}{*}{20} & 10 & $8,57^{\mathrm{f}}$ & 0,24 \\
& 15 & $8,72^{\mathrm{f}}$ & 0,24 \\
\hline
\end{tabular}

Keterangan : Angka rerata yang diikuti dengan huruf yang sama pada kolom yang sama tidak berbeda nyata pada uji Duncan 1\%

\section{Intensitas Warna (Kecerahan/L*, Kemerahan/a* dan Kekuningan/b*)} Hasil analisis sidik ragam Intensitas warna (Kecerahan, Kemerahan, Kekuningan) menunjukkan bahwa kombinasi perlakuan konsentrasi asam sitrat dan natrium bikarbonat serta interaksi antar perlakuan memberikan pengaruh sangat nyata $(\alpha=0,01)$ terhadap Intensitas warna serbuk effervescent temulawak.

Rerata kecerahan serbuk effervescent temulawak yang dihasilkan berkisar antara 58,47-60,23. Rerata kemerahan serbuk effervescent 
temulawak yang dihasilkan berkisar antara 14,03-14,63. Rerata kekuningan serbuk sari temulawak yang dihasilkan berkisar antara 45,20-46,90.

Tingkat kecerahan serbuk effervescent temulawak terendah didapatkan dari perlakuan konsentrasi asam sitrat $15 \%$ dan natrium bikarbonat $10 \%$ dengan nilai 58,47 dan tertinggi adalah dari perlakuan konsentrasi asam sitrat $20 \%$ dan natrium bikarbonat $20 \%$ dengan nilai kecerahan 60,23. Penambahan konsentrasi asam sitrat dan natrium bikarbonat semakin tinggi maka tingkat kecerahan serbuk effervescent temulawak juga semakin meningkat, karena warna asam sitrat dan natrium bikarbonat cenderung putih sehingga dengan adanya penambahan asam sitrat dan natrium bikarbonat semakin banyak maka tingkat kecerahan serbuk effervescent temulawak juga semakin meningkat.

Tingkat kekuningan $\left(b^{*}\right)$ serbuk effervescent temulawak terendah didapatkan dari perlakuan konsentrasi asam sitrat $10 \%$ dan natrium bikarbonat $10 \%$ dengan nilainya adalah 45,20. Sedangkan nilai tertinggi untuk parameter tingkat kekuningan $\left(b^{*}\right)$ serbuk effervescent temulawak didapatkan dari perlakuan konsentrasi asam sitrat $15 \%$ dan natrium bikarbonat $15 \%$ dengan nilainya 46,90. Semakin tinggi konsentrasi asam sitrat yang ditambakkan dan juga dengan semakin meningkatnya natrium bikarbonat maka tingkat kekuningan serbuk effervescent temulawak juga semakin meningkat.

Semakin tinggi konsentrasi asam sitrat dan natrium bikarbonat maka tingkat kecerahan $\left(\mathrm{L}^{*}\right)$ serbuk effervescent temulawak juga semakin tinggi (cerah), atau dapat dikatakan bahwa semakin tinggi konsentrasi asam sitrat dan natrium bikarbonat maka warna serbuk yang dihasilkan cenderung semakin putih. Hal ini disebabkan karena konsentrasi asam sitrat dan natrium bikarbonat yang ditambahkan semakin banyak menyebabkan kecerahannya semakin tinggi (cerah) ditandai dengan nilai kecerahannya lebih besar dari 50. Nilai kecerahan mendekati 100 maka tingkat kecerahannya semakin tinggi.

Demikian pula pada tingkat kekuningan, semakin nilainya positif kearah 100 maka tingkat kekuningannya semakin tinggi.Warna kuning dari serbuk effervescent temulawak disebabkan karena kandungan kurcumin dari temulawak. Karena dari asam sitrat dan natrium bikarbonat sendiri berwarna putih, oleh sebab itu dengan semakin banyaknya konsentrasi yang ditambahkan maka kecerahan serbuk sari temulawak semakin meningkat dan warna kuning dari serbuk effervescent temulawak semakin meningkat. Kurkumin stabil pada $\mathrm{pH}$ rendah, sehingga dengan penambahan asam sitrat yang semakin banyak menyebabkan warna serbuk effervescent temulawak juga semakin kuning. Karlsen (1985), menyatakan bahwa kurkumin stabil pada $\mathrm{pH}$ rendah, dalam keadaan asam akan berwarna kuning atau kuning jingga sehingga stabilitas optimum kurkumin dipertahankan pada 
pH kurang dari 7.

\section{pH}

Hasil analisis sidik ragam $\mathrm{pH}$ menunjukkan bahwa $\mathrm{pH}$ serbuk effervescent temulawak tertinggi didapatkan dari perlakuan konsentrasi asam sitrat $10 \%$ dengan nilai 5,28 sedangkan $\mathrm{pH}$ terendah didapatkan dari perlakuan konsentrasi asam sitrat 20\% dengan nilai 5,20. Perlakuan asam sitrat $15 \%$ dan $20 \%$ tidak terdapat perbedaan yang nyata tetapi pada perlakuan konsentrasi asam sitrat $10 \%$ berbeda dengan 2 perlakuan yang lain.

Semakin tinggi konsentrasi asam sitrat yang ditambahkan maka nilai $\mathrm{pH}$ serbuk effervescent temulawak semakin rendah (cenderung asam). Penurunan $\mathrm{pH}$ seiring dengan meningkatnya konsentrasi asam sitrat. Hal ini diduga karena ion $\mathrm{H}^{+}$dari asam sitrat memberikan tambahan pada effervescent temulawak sehingga $\mathrm{pH}$ nya turun. Ini sesuai dengan pernyataan Lehninger (1996), bahwa semakin banyak jumlah asam yang ditambahkan maka akan semakin besar pula ion $\mathrm{H}^{+}$ yang dilepaskan sehingga menurunkan nilai $\mathrm{pH}$.

\section{Kelarutan}

\section{Rerata kelarutan serbuk effervescent temulawak terendah didapatkan dari perlakuan penambahan konsentrasi asam sitrat $10 \%$ dan natrium bikarbonat $10 \%$ dengan nilai terendahnya adalah 66,68 , sedangkan rerata kelarutan serbuk effervescent temulawak tertinggi diperoleh dari}

perlakuan penambahan konsentrasi asam sitrat $10 \%$ dan natrium bikarbonat $20 \%$ dengan nilai tertingginya adalah 88,17 . Semakin tinggi penambahan konsentrasi asam sitrat dan natrium bikarbonat maka kelarutan serbuk effervescent temulawak akan semakin tinggi.

Adapun Rerata Kelarutan Serbuk Effervescent Temulawak pada Berbagai Kombinasi Perlakuan dapat dilihat pada Tabel 10.

Tabel 10. Rerata Kelarutan Serbuk Effervescent Temulawak pada Berbagai Kombinasi Perlakuan Konsentrasi Asam Sitrat dan Natrium Bikarbonat

\begin{tabular}{|c|c|c|c|}
\hline $\begin{array}{c}\text { Konsentr } \\
\text { asi Asam } \\
\text { Sitrat (\%) }\end{array}$ & $\begin{array}{c}\text { Konsentr } \\
\text { asi } \\
\text { Natrium } \\
\text { Bikarbon } \\
\text { at (\%) }\end{array}$ & $\begin{array}{c}\text { Kelarut } \\
\text { an }\end{array}$ & $\begin{array}{c}\text { DMRT } \\
(\boldsymbol{\alpha = 0 , 0} \\
\mathbf{1})\end{array}$ \\
\hline \multirow{2}{*}{10} & 10 & $66,68^{\mathrm{a}}$ & 1,30 \\
& 15 & $85,44^{\mathrm{d}}$ & 1,48 \\
\hline \multirow{2}{*}{15} & 20 & $88,17^{\mathrm{e}}$ & - \\
\hline \multirow{2}{*}{20} & 10 & $81,12^{\mathrm{bc}}$ & 1,43 \\
& 15 & $81,85^{\mathrm{c}}$ & 1,45 \\
& 10 & $85,20^{\mathrm{d}}$ & 1,47 \\
\hline & 15 & $80,19^{\mathrm{b}}$ & 1,37 \\
& 20 & $80,82^{\mathrm{b}}$ & 1,40 \\
\hline
\end{tabular}

Keterangan : Angka rerata yang diikuti dengan huruf yang sama pada kolom yang sama tidak berbeda nyata pada uji Duncan $1 \%$

Nilai kelarutan serbuk effervescent temulawak cenderung naik dengan semakin tingginya konsentrasi asam sitrat dan natrium bikarbonat. Hal ini disebabkan asam sitrat bersifat higroskopis sehingga semakin tinggi jumlah asam sitrat akan memperbesar 
proporsi bahan yang dapat laut dalam air. Selain itu juga dengan adanya natrium bikarbonat akan bereaksi cepat dengan asam sitrat yang dihasilkan karbondioksida. Mohrle menyatakan bahwa reaksi yang terjadi pada larutan effervescent adalah reaksi antara asam dan senyawa karbonat untuk menghasilkan gas karbondioksida yang memberikan efek sparkle atau rasa seperti pada air soda.

Semakin tinggi konsentrasi asam sitrat yang ditambahkan maka kelarutan akan meningkat. Asam sitrat mengandung air apabila bereaksi dengan natrium bikarbonat yang mengandung gas karbondioksida akan menghasilkan natrium sitrat, air dan akan terbentuk gas-gas karbondioksida tiga kali lebih cepat yang dapat membantu kelarutan, hal ini didukung oleh Nugroho (1999) yang menyatakan adanya gas-gas karbondioksida yang dihasilkan mampu membantu kelarutan tanpa melibatkan pengadukan manual dengan syarat semua komponennya sangat mudah larut dalam air.

\section{Kadar Gula Reduksi}

Rerata kadar gula reduksi serbuk effervescent temulawak terendah didapatkan dari perlakuan penambahan konsentrasi asam sitrat $10 \%$ dan natrium bikarbonat $10 \%$ dengan nilai terendahnya adalah 2,46 sedangkan rerata kadar gula reduksi serbuk effervescent temulawak tertinggi diperoleh dari perlakuan penambahan konsentrasi asam sitrat $15 \%$ dan natrium bikarbonat $20 \%$ dengan nilai tertingginya adalah $2,58 \%$.

Hasil analisis sidik ragam gula reduksi menunjukkan bahwa perlakuan konsentrasi asam sitrat dan natrium bikarbonat serta interaksi antar kedua perlakuan tidak memberikan pengaruh nyata terhadap kadar gula reduksi serbuk effervescent temulawak Penambahan asam sitrat dan natrium bikarbonat diduga tidak menyebabkan perubahan terhadap kandungan gula reduksi serbuk effervescent temulawak seperti reaksi fisik misalnya pemanasan atau reaksi kimia yang menyebabkan terjadinya perubahan gula reduksi.

\section{Kadar Antioksidan}

Hasil analisis sidik ragam kadar antioksidan memberikan pengaruh sangat nyata $\quad(\alpha=0,01)$ terhadap kadar antioksidan serbuk effervescent temulawak. Rerata kadar antioksidan pada berbagai kombinasi perlakuan konsentrasi asam sitrat dan natrium bikarbonat ditunjukkan Tabel 11.

Tabel 11 menunjukkan bahwa rerata kadar antioksidan serbuk effervescent temulawak tertinggi didapatkan dari kombinasi perlakuan konsentrasi asam sitrat $15 \%$ dan natrium bikarbonat $10 \%$ dengan nilai $63,96 \%$, sedangkan kadar antioksidan terendah didapatkan dari kombinasi perlakuan konsentrasi asam sitrat $10 \%$ dan natrium bikarbonat $15 \%$ dengan nilai $41,72 \%$.

Semakin meningkat konsentrasi asam sitrat maka kadar antioksidan serbuk effervescent temulawak semakin tinggi tetapi semakin tinggi natrium bikarbonat maka kadar antioksidannya 
semakin rendah. Konsentrasi asam sitrat yang semakin banyak akan melindungi senyawa antioksidan yang ada pada serbuk effervescent temulawak sehingga kadar antioksidannya semakin tinggi, karena antioksidan yang ada pada temulawak (kurkuminoid) akan stabil pada $\mathrm{pH}$ rendah. tetapi dengan semakin meningkatnya natrium bikarbonat akan dapat menurunkan kadar antioksidan sehingga kadarnya rendah, karena natrium bikarbonat bersifat basa dan antioksidan temulawak (kurkuminoid) tidak stabil pada $\mathrm{pH}$ basa.

Tabel 11. Rerata Kadar Antioksidan Serbuk Sari temulawak pada Berbagai Kombinasi Perlakuan Konsentrasi Asam Sitrat dan Natrium Bikarbonat

\begin{tabular}{|c|c|c|c|}
\hline $\begin{array}{c}\text { Konsentr } \\
\text { asi Asam } \\
\text { Sitrat } \\
(\%)\end{array}$ & $\begin{array}{c}\text { Natrium } \\
\text { Bikarbo } \\
\text { nat (\%) }\end{array}$ & $\begin{array}{c}\text { Kadar } \\
\text { Antioksid } \\
\text { an (\%) }\end{array}$ & $\begin{array}{c}\text { DMR } \\
\mathbf{T} \\
(\boldsymbol{\alpha = 0 , 0} \\
\mathbf{1})\end{array}$ \\
\hline & 10 & $54,76^{\mathrm{d}}$ & 3,45 \\
10 & 15 & $41,72^{\mathrm{a}}$ & 3,04 \\
& 20 & $46,53^{\mathrm{b}}$ & 3,38 \\
\hline & 10 & $63,96^{\mathrm{e}}$ & - \\
15 & 15 & $50,43^{\mathrm{c}}$ & 3,41 \\
& 20 & $43,75^{\mathrm{a}}$ & 3,19 \\
\hline & 10 & $50,59^{\mathrm{c}}$ & 3,43 \\
20 & 15 & $46,32^{\mathrm{b}}$ & 3,34 \\
& 20 & $43,96^{\mathrm{ab}}$ & 3,27 \\
\hline
\end{tabular}

Keterangan : Angka rerata yang diikuti dengan huruf yang sama pada kolom yang sama tidak berbeda nyata pada uji Duncan $1 \%$

\section{Uji Organoleptik}

\section{Rasa}

Hasil uji organoleptik menunjukkan bahwa rerata nilai kesukaan panelis terhadap rasa effervescent temulawak mempunyai nilai terendah 3,15 didapatkan dari kombinasi perlakuan penambahan konsentrasi asam sitrat $20 \%$ dan natrium bikarbonat $10 \%$ sedangkan nilai tertinggi 5,85 didapatkan dari kombinasi perlakuan konsentrasi asam sitrat $15 \%$ dan natrium bikarbonat $10 \%$.

Hasil analisis Uji Friedman menunjukkan bahwa kombinasi perlakuan konsentrasi asam sitrat dan natrium bikarbonat memberikan pengaruh nyata terhadap rerata kesukaan rasa effervescent temulawak. Kombinasi perlakuan terbaik tingkat kesukaan rasa diperoleh dari konsentrasi asam sitrat $15 \%$ dan natrium bikarbonat $10 \%$.

\section{Warna}

Hasil uji organoleptik menunjukkan bahwa rerata nilai kesukaan panelis terhadap warna effervescent temulawak semakin meningkat rerata kesukaan panelis terhadap warna dengan semakin meningkatnya konsentrasi asam sitrat dan natrium bikarbonat. Rerata nilai kesukaan panelis terhadap warna terendah adalah 2,12 yaitu pada kombinasi perlakuan konsentrasi asam sitrat $20 \%$ dan natrium bikarbonat $20 \%$, sedangkan rerata nilai kesukaan panelis terhadap warna tertinggi didapatkan dari kombinasi perlakuan konsentrasi asam sitrat $15 \%$ dan natrium bikarbonat $10 \%$ sebesar 5,00. Hasil analisis Uji Friedman menunjukkan bahwa kombinasi 
perlakuan konsentrasi asam sitrat dan natrium bikarbonat memberikan pengaruh nyata terhadap rerata kesukaan panelis terhadap warna effervescent temulawak. Kombinasi perlakuan terbaik terhadap warna diperoleh dari konsentrasi asam sitrat $20 \%$ dan natrium bikarbonat $10 \%$.

\section{Aroma}

Hasil uji organoleptik menunjukkan bahwa rerata nilai kesukaan panelis terhadap aroma effervescent temulawak mempunyai nilai rerata terendah sebesar 2,60 yaitu pada kombinasi perlakuan konsentrasi asam sitrat $15 \%$ dan natrium bikarbonat $20 \%$, sedangkan rerata nilai kesukaan panelis terhadap aroma tertinggi didapatkan dari kombinasi perlakuan konsentrasi asam sitrat $10 \%$ dan natrium bikarbonat $20 \%$ yaitu 4,64.

Hasil analisis Uji Friedman menunjukkan bahwa kombinasi perlakuan konsentrasi asam sitrat dan natrium bikarbonat memberikan perbedaan nyata terhadap rerata kesukaan aroma panelis. Kombinasi perlakuan terbaik kesukaan aroma panelis diperoleh dari penambahan konsentrasi asam sitrat $10 \%$ dan natrium bikarbonat $20 \%$.

\section{Pemilihan Perlakuan Terbaik}

Hasil perhitungan perlakuan terbaik pada tahap II untuk parameter fisikokimia serbuk effervescent temulawak yaitu dari kombinasi perlakuan konsentrasi asam sitrat $10 \%$ dan natrium bikarbonat $20 \%$ dengan karakteristik sebagai berikut: kadar air 7,48\%; tingkat kecerahan (L*) 59,37; tingkat kemerahan $\left(\mathrm{a}^{*}\right)$ 14,53; tingkat kekuningan $\left(\mathrm{b}^{*}\right)$ 46,50; $\mathrm{pH}$ 5,33; kelarutan 88,17; kadar gula reduksi $2,49 \%$ dan kadar antioksidan 46,53\%

Hasil perhitungan parameter organoleptik didapatkan perlakuan terbaik pada serbuk effervescent temulawak dengan perlakuan terbaik yang tidak sama dengan parameter fisikokimia yaitu kombinasi perlakuan konsentrasi asam sitrat $15 \%$ dan natrium bikarbonat $10 \%$ dengan karakteristik sebagai berikut: rerata tingkat kesukaan panelis terhadap warna 6,25; rasa 5,85 dan aroma 5,15. Sehingga perlakuan terbaik dari tahap II diambil dari data organoleptik karena penilaian oleh panelis terhadap suatu produk lebih diutamakan daripada parameter fisikokimia.

\section{KESIMPULAN DAN SARAN}

\section{Kesimpulan}

Kesimpulan yang dapat diambil dari penelitian ini adalah:

1. Pada tahap I, perlakuan konsentrasi dekstrin dan suhu pengering menunjukkan pengaruh sangat nyata $(\alpha=0,01)$ terhadap kadar air, intensitas kecerahan ( $\left.\mathrm{L}^{*}\right)$, kemerahan $\quad\left(\mathrm{a}^{*}\right)$, kekuningan, reabsorbsi, $\mathrm{pH}$, rendemen, gula reduksi dan antioksidan serbuk sari temulawak.

2. Perlakuan konsentrasi dekstrin $20 \%$ dan suhu pengering $50^{\circ} \mathrm{C}$ 
merupakan perlakuan terbaik tahap I dari serbuk sari temulawak yang memiliki karakteristik kadar air $10,11 \%$; tingkat kecerahan $\left(\mathrm{L}^{*}\right)$ 55,10 ; tingkat kemerahan $\left(\mathrm{a}^{*}\right)$ 14,56; tingkat kekuningan ( $\left.b^{*}\right)$ 44,20; rendemen 24,63\%; pH 5,63; reabsorbsi air 2,78; kadar gula reduksi $1,88 \%$ dan kadar antioksidan $62,27 \%$ sedangkan rerata tingkat kesukaan panelis terhadap warna 5,55; rasa 5,95 dan aroma 4,15

3. Pada tahap II, perlakuan konsentrasi asam sitrat dan natrium bikarbonat menunjukkan pengaruh sangat nyata $(\alpha=0,01)$ terhadap kadar air, intensitas kecerahan $\left(\mathrm{L}^{*}\right)$, kekuningan $\left(b^{*}\right)$, kelarutan dan antioksidan. Pada parameter $\mathrm{pH}$ memberikan pengaruh nyata $(\alpha=$ 0,05) sedangkan intensitas kemerahan $\left(a^{*}\right)$ dan gula reduksi tidak berpengaruh nyata

4. Perlakuan konsentrasi asam sitrat $10 \%$ dan natrium bikarbonat $20 \%$ merupakan perlakuan terbaik tahap II yang memiliki karakteristik kadar air $7,48 \%$; tingkat kecerahan $\left(\mathrm{L}^{*}\right)$ 59,37; tingkat kemerahan ( $\left.\mathrm{a}^{*}\right)$ 14,53; tingkat kekuningan $\left(\mathrm{b}^{*}\right)$ 46,50; pH 5,33; kelarutan 88,17; kadar gula reduksi 2,49\% dan kadar antioksidan $46,53 \%$

\section{Saran}

1. Masih terdapat endapan dalam minuman setelah serbuk effervescent temulawak dilarutkan, sehingga perlu adanya penelitian lebih lanjut untuk meminimalkan atau menghilangkan endapan yang ada dengan memperkecil ukuran bubuk partikel.

2. Masa simpan produk belum diketahui secara pasti, sehingga perlu penelitian lebih lanjut tentang masa simpan produk dengan beberapa macam bahan penstabil..

\section{DAFTAR PUSTAKA}

Afifah, E., dan Tim Lentera. 2003. Khasiat Dan Manfaat Temulawak Rimpang Penyembuh Aneka Penyakit. Agromedia Pustaka. Jakarta.

Agatha, 2006. Optimasi Formula Granul Effervescent Ekstrak Temulawak (Curcuma xanthorrhiza Roxb) Dengan Kombinasi Asam Sitrat , Asam Tartrat (Aplikasi Metoda Desain Faktorial). Intisari. Universitas Sanata Drama. Yogyakarta.

Anonymous, 1985. Color Reader CR10 Operation Manual. Minolta, Japan.

Anonymous, $1995 . \quad$ Farmakope Indonesia, Edisi IV, 50, 338, 354, 424, 591, 654. Departemen Kesehatan. Republik Indonesia. Jakarta.

Anonymous, 2002. Kajian Keamanan Bahan Tambahan Pangan Pemanis Buatan.

http://www.pom.go.id/nonpublic/m 
akanan/standart//News1.html.9.

Tanggal Akses 9 April 2007.

Anonymous, $2004 . \quad$ Prospek

Temulawak. Suara Merdeka edisi

$24 \quad$ Nopember 2004

http://www.suaramerdeka.com .

Tanggal akses 9 Juni 2006.

Anonymous, 2005.

Bunga

Kecombrang, Deodoran Alami,

Dan Antimikroba. Suara Merdeka.

Cyber News. Nasional.

Anonymous, 2007. Asam Sitrat.

Wikipedia Indonesia, ensiklopedia bebas berbahasa Indonesia. http://id.wikipedia.org/wiki /asam sitrat. Tanggal akses 27 maret 2007.

Ansel, H. 1989. Pengantar Bentuk Sediaan Farmasi. Edisi ke 4. UI Press. Jakarta.

AOAC. 1990. Official Method of Analysis of the Association of Official of Analytical Chemist. $11^{\text {st }}$ Edition. Washington.

Aref, M. 1987. Ilmu Meracik Obat Berdasar Teori Dan Praktek. Universitas Gajahmada Press. Yogyakarta.

Arifin, Z., Kardiyono. 1985. Temulawak Dalam Pengobatan Tradisional. P.T. Air Mancur. Jakarta.

Buckle, K.A. R.A, Edwars, G.H. Fleet and M. Wotton., 1987. Terjemahan Purnomo, H. dan Adiyono. Ilmu Pangan. Universitas Indonesia Prees. Jakarta.

Dart, R.K. 1996. Microbiology For The Analytical Chemist. The Royal Scociety of Chemistry. UK.
De Man, J.M. 1997. Kimia Makanan. Penerjemah K. Padmawinata. Penerbit ITB. Bandung.

Desroier, N.W. 1988. Teknologi Pengawetan Pangan. (terjemaahan Muchji Muljohardjo). UI - Press. Jakarta.

Dewi, A.K. 2000. Pengaruh Jenis Dan Konsentrasi Bahan Pengisi Terhadap Sifat fisik, Kimiawi Dan Organoleptik Serbuk Effervescent Temulawak

(Curcuma xanthorrhiza Roxb). Skripsi. FTP. UNIBRAW. Malang.

Djakamihardja, S.P., Setyadiredja dan I. Sudjono. $1999 . \quad$ Budidaya Tanaman Temulawak (Curcuma xanthorrhizza Roxb) Dan Prospek Pengembangannya di Indonesia. Abstrak. Jurusan Budidaya Pertanian. Fakultas Pertanian Universitas Padjadjaran. Bandung. Dwidjoseputro, D. 1998. Dasar-Dasar Mikrobiologi. Djambatan. Jakarta.

Fardiaz, S. 1992. Mikrobiologi Pangan. Gramedia pustaka Utama, Jakarta. Fennema, O.R. 1976. Principles of Foods Science. Marcel Dekker. Inc. New York.

Ganiswarna, S.G. 1995. Farmakologi dan Terapi Edisi IV. Bagian Farmakologi Fakultas Kedokteran. Universitas Indonesia. Jakarta.

Hadi, S. 1999. Manfaat Temulawak Ditinjau Dari Segi Kedokteran. Abstrak. Fakultas Kedokteran. UNPAD. Bandung.

Hargono, D. 1985. Prospek Pemanfaatan Temulawak. Direktorat Pengawasan Obat 
Tradisional. Dirjen POM. Depkes R.I. Jakarta.

Indriati A., 2001. Analisis Antioksidan

Pada Buah Jambu Mete (Annarcardium occidentalle L.) Tesis. Program Pascasarjana Universitas Brawijaya Malang.

Kusumawardani, A.N. 2006. Kajian Penambahan Antioksidan Terhadap Mutu Simplesia Temulawak (Curcuma xanthorrhiza Roxb). Skripsi. FATETA. IPB. Bogor.

Liang, O.B., Y. Apsarton, T. Widjaja, dan S. Puspa. 1999. Beberapa Aspek Isolasi, Identifikasi Dan Penggunaan KomponenKomponen Curcuma xanthorrhiza Roxb, Dan Curcuma domestica Val. Abstrak. Pt Darya Varia Laboratoria. Jakarta.

Majeed, M., V. Badinaev, U. Shivakumar, R. Rajendran. 1995. Curcuminoids: Antioksidant Phytonutrients. NutriScience Publishers Inc., New Jersey.

Muchtadi, D. 1977. Pengolahan Hasil Pertanian II. IPB. Bogor.

Naim, R. 2004. Senyawa Antimikroba dari Tanaman. Fakultas Kehutanan IPB.

Bogor. http://www.kompas.com/Senyawa Antimikroba. Akses 9 November 2006.

Nirbita, T. 2002. Uji Aktivitas Antioksidan dan Antibakteri ( Esccheria coli dan Staphylococcus aureus ) Kunyit putih dan Produk Olahannya ( Bubuk dan Effervescent Kunyit Putih). Skripsi. Jurusan Teknologi Hasil
Pertanian. Fakultas Teknologi Pertanian. Universitas Brawijaya. Malang.

Oehadian, H., M.E. Sjafiudin dan Nuraini. 1999. Efek Anti Jamur Dari Curcuma Xanthorrhizza Roxb (Temulawak) Terhadap Beberapa Jamur Golongan Dermatophyta. UNPAD. Bandung. Ramlan, Aseng. 1999. Etnobotani Marga Curcuma Di Jawa Barat. Fakultas Matemátika Dan Ilmu Pengetahuan Alam. Unpad.

Reynolds, James E.F. 1982. Martindale The Extra Pharmacopolia, Edition Twenty Eigth. The Pharmacentical Press. London.

Potter, N.W. 1973. Food Science. $2^{\text {th }}$. The Avi Publishing Company, Inc. New York. 156 - 185.

Pramono Suwijiyo, (1995). Kontrol Efektifitas Berbagai Cara Pembuatan Ekstrak Temulawak Dilihat Dari Kandungan Kurkumin Dan Minyak Atsirinya. Abstrak. Fakultas Farmasi UGM. Yogyakarta.

Prawira, L. 1996. Pemanis Rendah Kalori: Aspartam. Buletin Teknologi dan Industri Pangan Vol. VII (3). IPB. Bogor.

Purnomowati, S., A. Yoganingrum. 1997. Tinjauan Literatur Temulawak (Curcuma xanthorrhiza Roxb). Pusat Dokumentasi Dan Informasi Ilmiah, Lembaga Ilmu Pengetahuan Indonesia. Jakarta. 
Rukmana, R., 2000. Temulawak Tanaman Rempah dan Obat. Kanisius. Yogyakarta.

Setijadi, T. (1985). The Identification of The Active Ingredients of Curcuma Xanthorrhiza Rox and Curcuma Longa Vahl. After Extraction With Supercritical Carbondioxide. PT. Darya Varia Laboratoria. Bogor.

Sidik., Moeljono., A. Muhtadi., M. Sirait., dan Moesdarsono. 1999.1 TEMULAWAK (Curcuma xanthorrhiza Roxb.) Yayasan Pengembangan Obat Bahan Alam Phytomedica. Jakarta.

Sirait, M., 1979. Materia Medika Indonesia. Departemen Kesehatan Republik Indonesia. Jakarta.

Soewarno., T. Soekarto. 1985.

Penilaian Organoleptik. Bhatara

Karya Aksara. Bogor.

Sudarmadji, S., B. Haryono., dan Suhardi. 1997. Prosedur Analisa

Untuk Bahan Makanan dan

Pertanian. Liberty. Yogyakarta.

Sugiharto, A.R. 2004. Pengaruh Lama

Penyimpanan Temulawak Bentuk

Segar Dan Bubuk Terhadap Aktivitas Antioksidan Dan Antibakteri. Skripsi. FTP.

UNIBRAW. Malang.

Sukasedati, N., Sutrisno., L.K. Darusman., M. Januwati., A.S.

Ranti., I. Batubara., dan E.I. Kumala. 2004. Prosiding Fasilitas Forum Kerjasama Pengembangan Biofarmaka. Yogyakarta.
Sumiaty, 1997. Minuman Berkhasiat dari Temulawak (Curcuma Xanthorriza). Fakultas Teknologi Pertanian. IPB. Bogor.

Suparti, W. 2000. Pembuatan Pewarna Bubuk dari Ekstrak Angkak: pengaruh Suhu, Tekanan dan Konsentrasi Dekstrin. Tesis. Program Pascasarjana. Universitas Brawijaaya. Malang.

Susilowati., B. Subagjo., dan W. Dyatmiko. 1999. Pengaruh Daya Antimikroba Dari Rimpang Curcuma Domestical Val. Terhadap Bakteri Escherichia Coli. Abstrae. Pusat Penelitian Pengembangan Obat Tradisional. Universitas Airlangga. Jakarta.

Susilo, A.O. 2005. Pembuatan Bubuk Effervescent Dari Ekstrak Ubi Ungu Jepang (Ipomoea batatas var. Ayammurasaki). Skripsi. FTP. Universitas Brawijaya. Malang.

Sutjipto., Djumidi, dan J.R. Hutapea. (1985). Pengaruh Waktu Dan Pangeringan Dalam Tanur Pemanas, dan Tabal Irisan Terhadap Kadar Minyak Menguap Rimpang Temulawak. UNPAD. Bandung.

Taryono, E.M., Ramat, S. Dan Sardino, A. 1987. Plasma Nuffah Tanaman Temu-Temuan. Balai Penelitian Rempah dan Obat. Bogor. 3 (1) : 47.

Wahid, P., Soediarto. 1999. Pembudidayaan Tanaman Temulawak. Abstrae. Balai Penelitian Tanaman Rempah dan 
Obat. Badan LitbangPertanian.

Departemen Pertanian. Jakarta.

Wahono, T., 2006. Dasar-dasar Uji Indrawi. Fakultas Teknologi Pertanian. Universitas Brawijaya Malang.

Yitnosumarto, S. 1993. Percobaan, Perancangan, Analisis dan Interpretasinya. PT Gramedia Pustaka Utama. Jakarta. 
